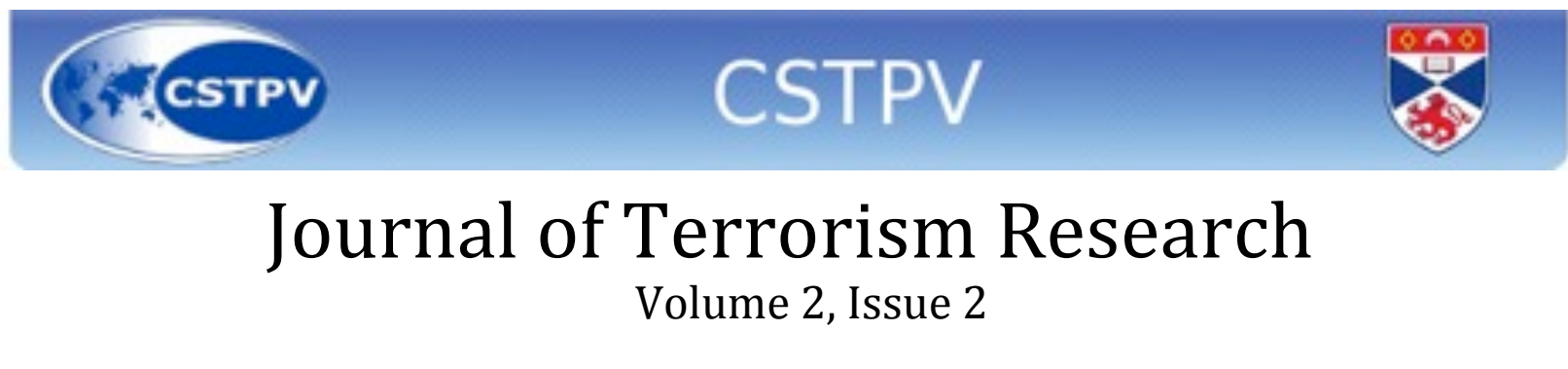

\title{
Security, Identity, and the Discourse of Conflation in Far-Right Violence
}

\author{
by Jeffrey Stevenson Murer
}

\begin{abstract}
:
In the aftermath of Anders Breivik's shooting spree and bombing in Norway, many people asked where did the anger and the violence come from? The article examines the contemporary trends in political and social discourses to conflate opponents with enemies. Popular discourses, television and on-line media, radio talk shows and even newspaper spread the language of threat and insecurity, and the idea that the biggest threats may be the people in our own neighbourhoods, in our own cities, on our own streets. These threatening individuals are those that do not quite fit in; they are familiar foreigners. Similarly it explores the discourses of who should be afforded trust and protection within multi-ethnic, multi-lingual, multi-cultural political and social environments, who exhibits social membership and who should be excluded. The language of austerity and shortage suggests that security is not a human right that all people are entitled to equally. Rather if states can only afford to protect certain people, then by default the state chooses to actively not protect others. This article explores the social and physical consequences these decisions have, particularly when certain individuals decide that they will do what others only talk about: eliminate enemies.
\end{abstract}

It is our own wickedness -not foreigners. We have produced the poison.

-- Norwegian Professor Thomas Hylland Eriksen [1]

There is no Roma problem; rather there is a Nazi Problem.[2]

-- Former Hungarian Prime Minister Ferenc Gyurcsány

\section{Prologue:}

In autumn 2010 immigrant communities and people of color in Malmö, Sweden had good reason to be afraid. In September's parliamentary election a small far-right political party that wishes to significantly curtail rights and access for immigrants -- Sweden Democrats (SD) -- cleared the threshold, garnering $6 \%$ of the vote, and won 20 seats. The party, which demands cuts in immigration, described Islam as Sweden's biggest threat since the Second World War.[3] In inflammatory television advertisements, which Swedish TV4 refused to air, the SD depicted a group of figures dressed in Burkas, jostling against an elderly white woman, pushing a walker no 


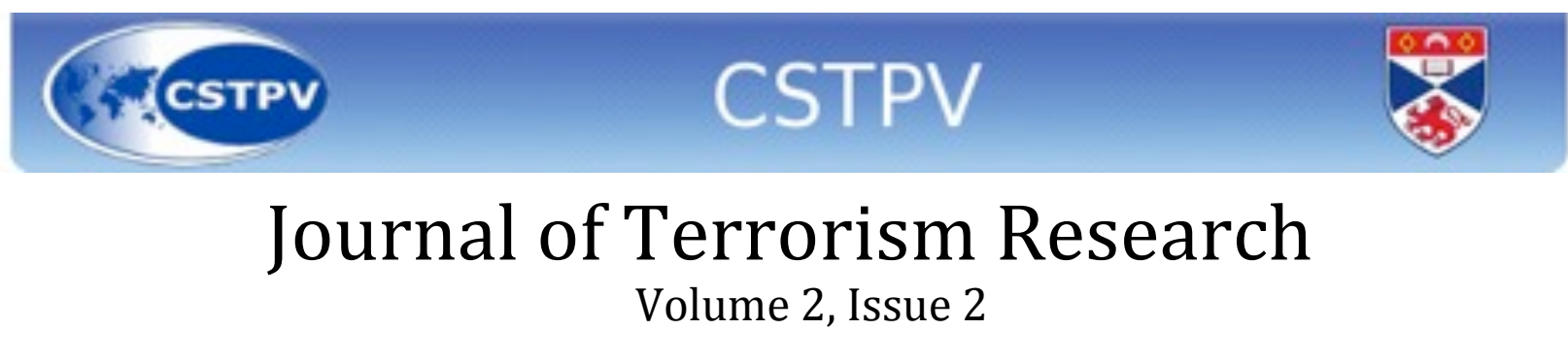

less, to get to the head of the benefits queue. The voice over said "politics is all about priorities; now you have a choice." Coincident to this small party's significant electoral showing, immigrants and minorities were being targeted by a gunman as they waited at lonely bus stops, walked along footpaths, or just sat in their cars.Although the shooting spree began nearly a year before the September election, there was a sense that the pace of the shootings quickened following the elections. In total there were twenty-one shootings, which killed one person and injured many others.[4] The daughter of Turkish immigrants, who was afraid to go outside, told BBC Radio 4 that she was angry that her "entire life is being dictated by a single gunman."[5] Indeed the gunman held Malmö rapt. Dubbed the "Race Gunman"[6] or the "racist sniper", Peter Mangs was eventually arrested on 7 November and was formally charged with one count of murder and five counts of attempted murder on 27 January 2011.[7] Unfortunately this was not the first time this kind of thing has happened, nor would it be the last.

\section{Selecting Targets:}

After the July 2011 shootings in Norway, media and political attention shifted to examine threats posed from far-right political extremists, and rightfully so. Although the Oslo car bomb and subsequent mass shooting took much of the mainstream press and so-called median voters across Europe by surprise, elements of the far-right have been in action for a quite some time, and more recently their violence has escalated, intensified, and grown more protracted. This article examines how such intense, and at times widespread violence goes largely unnoticed; it also examines whom is targeted by these groups, and how mainstream politics support and even legitimate this violence.

In June 2011 the U.N. agency for refugees, the UNHCR, issued warnings that in certain Athens neighborhoods "fascist groups had established their own lawless regimes."[8] During three days of racist attacks in May, gangs of neo-fascists rampaged through prominently Asian and African immigrant areas stabbing more than 25 people. In reaction the UNHCR wrote: "there has been a dangerous escalation in...racist violence targeting indiscriminately aliens, based solely on their skin color.'[9] Naim Elgandour, the Egyptian born head of the Muslim Association in Greece told the Associate Press that he believed that there may be as many as 5,000 active hardcore right-wing extremists in Athens alone, who "are gaining sympathy and tolerance by the day."[10] Gone from far-right politics is the stigma associated with the military dictatorship that ruled Greece from 1967-1974. But this is not a new phenomenon. Twenty years ago immigrants were being targeted for their skin color at the opposite end of Europe, in an area long thought of for its tolerance and social democracy. 


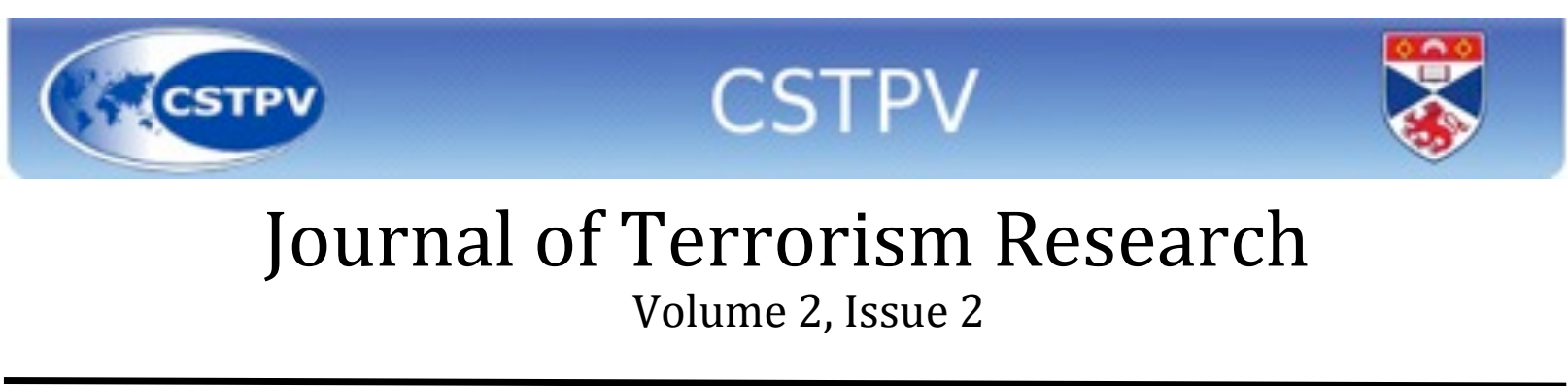

From August 1991 to January 1992 John Ausonius shot eleven people in Stockholm and Uppsala, killing one. He became known popularly and in the media as "Laserman" as he used a laser-guided sight on his rifle. As T-shirts appeared on the streets of Stockholm celebrating his exploits, it became clear that the violence directed at Stockholm's immigrant communities was different.[11] It was violence directed at the other. Quickly Laserman became a local "hero", taking upon himself what so many others would only talk about. For those that lionized him knew that they would never be the target of his rage or rifle, for they felt themselves to be, and obviously recognizable as, "true Swedes." Arrested in 1992 and sentenced to life in prison in 1994, Ausonius gave extensive interviews to Gellert Tamas, to whom he admitted that he was inspired by the 1991 election debates about immigrants, when a similar, small vehemently antiimmigrant party, New Democracy, set the tone and terms of debate, won a number of seats in the parliament, and set about to denounce and limit any immigrants' access to the largess of the state. Ausonius told Tamas that he "felt moral support; that the people stood behind him." He stated explicitly that he felt " political support from the (populist anti-immigrant party) New Democracy, and also from other political parties."[12] He felt he was doing the right thing in defense of Swedish people.

With Anders Breivik's recent car bombing in Oslo, and shooting spree on Utøya Island, the specter of the far-right rising over the European political landscape has been recognized. While it may be easy to dismiss his claim that he acted to defend a Christian Europe as that of a single, perhaps deranged, individual acting alone, he was inspired by the political climate around him. Beyond Oslo he reached out to groups like the English Defense League (EDL), although there is no sign of a larger conspiracy with the group for further action. Nevertheless, prominent British businessman and funder of the EDL, Alan Lake, appeared on Norwegian Television saying that he would be happy to execute extremist Muslims. The Independent reports that Lake said: "[Such Muslims] are not respecting that which respects the state and as far as I am concerned I'd be happy to execute people like that.'[13] Broader political society often takes solace in the notion that such utterances are anomalous, and that such individuals are rare, isolated, loners, and yet these individuals often act out the implied imperatives of mainstream discourses and political themes. These themes are becoming increasing expressed in dire terms, which allow for no compromise, suggest that "whole ways of life" may be in danger of becoming extinct, and require steadfast and decisive action.

\section{Ideocide: You are with us or against us!}

Since $9 / 11$ the political discussion surrounding terrorism in the mainstream media has been flat. One factor is a tendency in the US and UK for the "media to ignore the social causes of 


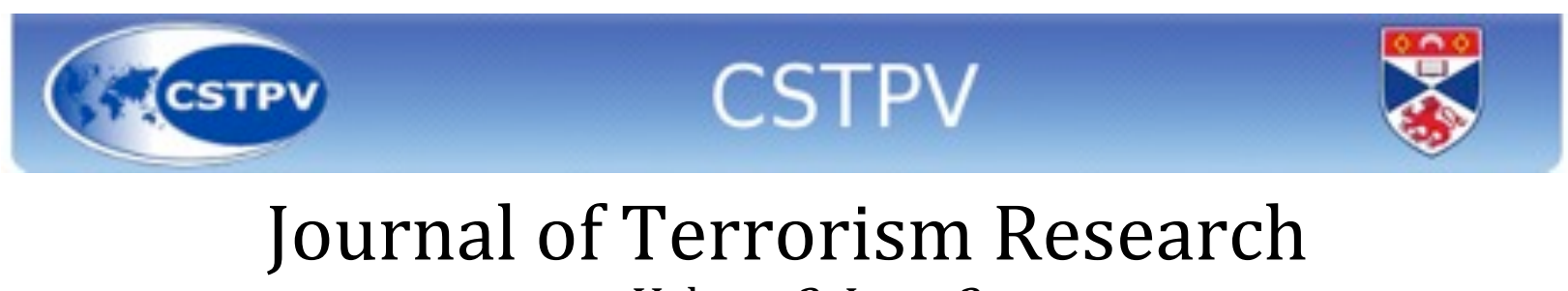

Volume 2, Issue 2

terrorism."[14] Rather terrorists are treated as objects of fear, and as such they are not social or political beings. This forestalls the possibility of engaging in any reasonable debate; it also renders such actors as essentially non-political. Aly and Green suggest that the result is a notion that "terrorists are motivated by inner torments and not politics."'[15] What motivates the terrorist is that "they hate us" or "they hate our freedom" or "our way of life." All "terrorists" become linked together regardless of their political environments, and as such are characterized by their non-normative behavior. The flipside of this proposition becomes that all people who engage in "non-normative behavior", those who engage positions outside of what is perceived as mainstream political activity, can come to be seen as "terrorists." During the "Dirty War" in Argentina (1976-1983) this sentiment was pervasive following General Jorge Rafael Videl's declaration: "A terrorist is not just someone with a gun or a bomb, but also someone who spreads ideas that are contrary to Western and Christian civilization.”[16]

Arjun Appadurai has identified such assertions as "ideocide", whereby people, concepts and ways of life come to be regarded as so noxious and so "outside the circle of humanity as to comprise an appropriate target for what Orlando Patterson called 'social death."'[17] The danger is to mistake a critique of hegemonic discourse as an act standing "outside of the circle of humanity." Those cast as "them" are subject to threats of violence in the name of self-defense by the group-self, which is defined as those being under threat from the "violence" of the other. In this way, the boundary between "us" and "them" is set through two performative acts: the first is the act of feeling threatened. If you are not under threat, if you do not feel threatened by an insurgent minority, then you are not part of the "substantive majority" under threat. The second is to act against the "threat" - the minority. This may appear tautological but it is an important act of distinction: what the "substantive majority" has in common is the feeling of being under threat.

Those who do not share this fear are either part of the threating minority, insinuating the paranoid-schizoid construction of "you are with us or against us", or they are part of the "substantive majority" but do not know it yet. This itself is a conflation, for it shifts the understanding of the role of minority as a dynamic, liberal, procedural concept - one which is in constant flux and reorganization - to an ethno-linguistic-cultural one that is fixed and engaged in a static zero-sum game. Here the dissenter - the procedural minority of opinion - is linked to a threat to transform the majority into a minority; that is, the minority represents a threat to defeat all that the "majority" stands for. The very existence of an oppositional minority is noxious to the majority. But this too morphs a particular political position into "substantive majority." These are what Appadurai describes as "predatory identities", which incite self-understood or declared "majorities to fear that they are becoming minorities, and fear that minorities are becoming majorities."[18] 


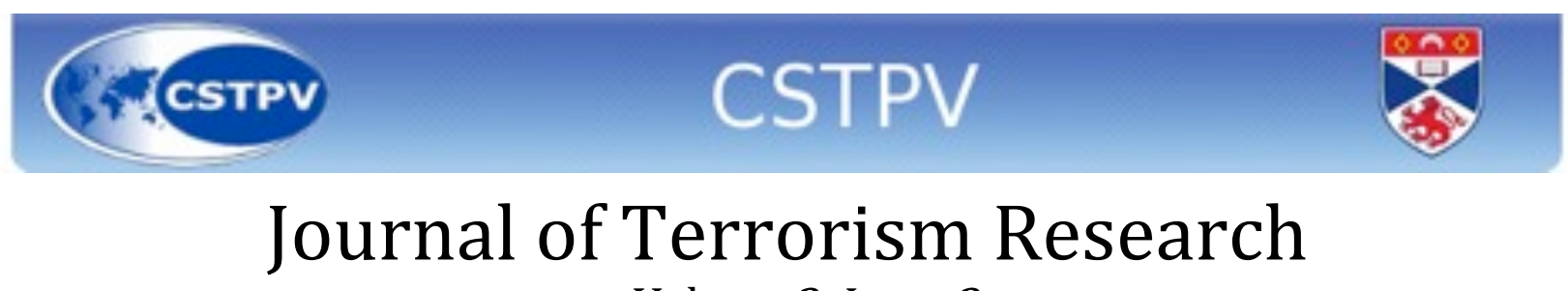

Volume 2, Issue 2

In defense against small numbers becoming large, some take matters into their own hands, transforming social death into physical death. In these moments of fear - fear of the economy, of terrorism, of the uncertain and the unknown - the paranoid-schizoid position that divides the world into "us" and "them" engenders discourses to eliminate the threat - to eliminate the other. Just as political discourse can mobilize civic action, so too can it mobilize violent action. This conflation of opponents and enemies transforms potential allies into adversaries, both discursively and socially Discursively the "majority" claims the right or the power to define membership in the collective, often in a fashion beyond both normative and juridical practice. Yet, it is not a right for them to claim.

In practice, this hostility, this intolerance, makes it difficult for members of a society who have been declared as "other" to believe they are welcome within the very society they call home. It becomes increasingly difficult to have deep emotional attachments to a place or society that is discriminatory, prejudiced, or actively working to frighten, displace, or harm you. This can lead to a vicious circle in which those who are rhetorically "expelled" retreat into their own neighborhoods, cultural practices, or social networks.[19] The act of seeking moral and social support among allies can be read as disengagement, often by the very initiators of the rhetorical expulsion. Through the construction of a narrative disengagement of the other, the initiators of the rhetoric of expulsion often justify physical acts of violence against the other; any resistance is further proof of their very "otherness." It is a rhetorical trap with potentially physically harmful consequences. In the name of being fearful, members of the self-described or proclaimed majority, commit acts of violence that terrify other communities.

For example, Krisztina Morvai, a Member of the European Parliament from the Hungarian political party Jobbik - a Hungarian play on words meaning both the better choice and a more right-wing option, and which The Guardian recent described as a "neo-fascist party[20] -nominated György Budaházy for the Council of Europe's Human Rights Prize for languishing in a Hungarian jail for more than a year without being charged.[21] Only a few days later, Budaházy and sixteen associates were indicted on suspicion to commit terrorism for bomb plots, attacks on journalists including the severe beating of a television presenter, arson attacks, bomb making, and the fire bombings of homes and buildings belonging to Socialist politicians. Morvai can often been seen walking the halls of the European Parliament in Brussels wearing a "Free Budhazáy" t-shirt.[22]

As Jobbik and the right in general have continued to garner political strength in Hungary recently, much of their rhetoric has centered on the question of who is a "true Hungarian." In April 2011, the Hungarian Red Cross offered bus evacuation to nearly three hundred Roma who feared further attacks on their village of Gyöngyöspata, which had been under "patrol" for four weeks by the Jobbik supported group Civil Guard Association for a Better Future (Szebb Jövöért 


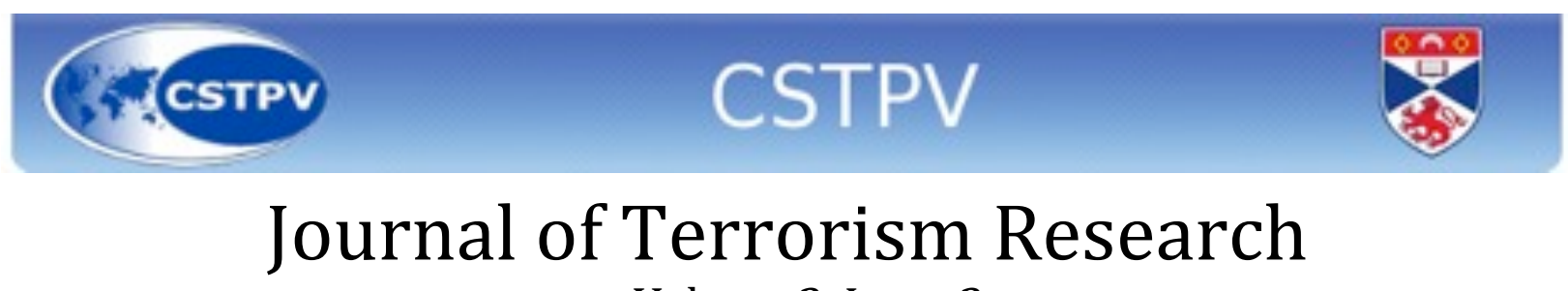

Volume 2, Issue 2

Polgárör Egyesület). According to Hungarian Watch, the group woke Roma residents in the night, prevented them from going about their business, threatened them with weapons, and severely beat 17.[23] The Szebb Jövöért claimed that they were trying to protect Hungarians and prevent "Gypsycrime".[24] The Jobbik Member of Parliament Gergely Rubi said that the group was in Gyöngyöspata to "improve public order and security."[25] The suggestion is that Roma are not in need of security or protection, but are the threat, to which the former Hungarian Prime Minister Fernec Gyurcsány replied: “there is no Roma problem, there is a Nazi problem.”[26]

\section{Muslim $=$ Threat}

In Denmark, the distinction between "New Danes" and unqualified Danes represents the boundary between entitlement to state benefits as the autochthonous, and the perpetually insecure position of being [barely] tolerated as the allochthonous. In the Netherlands Geert Wilders' growing political prominence appears to signal the continued collapse of tolerance that was notably initiated with the parliamentary bid of Pim Fortuyn in 2002. Wilders has echoed many of Fortuyn's sentiments, such as writing in the De Volkskrant "I have had enough of Islam in the Netherlands; let not one more Muslim immigrate."[27] He has called the Koran a "fascist book" which should be banned, and his denouncements of Islam have been so inflammatory that he is presently being tried in court for "inciting hatred against Muslims."[28] Similar to the electoral performance of Jobbik, and better than that of the Sweden Democrats, Wilders' Freedom Party is the third largest party in the Netherlands, having won 24 of the 150 seats in last summer's parliamentary election. The entire freedom Party campaign can be seen as a screed against Muslims in the Netherlands.

Unfortunately there has also been a shift in the United States whereby "Muslim" is becoming a pejorative term, suggesting outsider status and indicating potential danger. Much of this rhetoric has been associated with the U.S. Tea Party movement, and became prominent over last summer's plans for an Islamic cultural center to be built in Lower Manhattan, a number of blocks away from World Trade Centre reconstruction site. These plans suddenly became described as the "plot" to build a "mosque at Ground Zero", and sparked heated partisan debate across the American polity. In towns far from New York, often with few Muslims, similar debates and controversy roiled over during the long hot days of summer. At the end of August 2010, gunshots were fired at mosque in Murfreesboro, Tennessee, a suburb of Nashville, not long after that state's lieutenant governor, said at a rally of opponents to the Murfeesboro mosque, "that is Islam is a cult and not a religion."[29] In front of a Temecula, California mosque one protestor held aloft a sign that read "Mosques are Monuments to Terrorism." [30] 


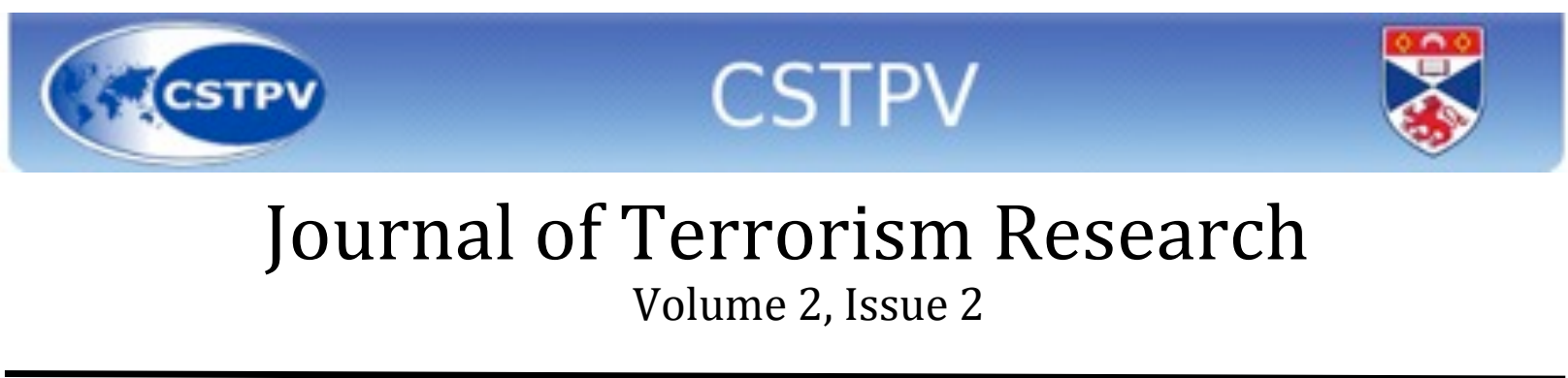

But not only are Muslims perceived as enemies, but enemies are perceived as Muslim. In an August 2010 Pew Charitable Trust poll, nearly one-in-five Americans believed that President Obama is a Muslim. Moreover this mistaken view -- Obama is a practicing Christian - has a political hue to it. $34 \%$ conservative Republicans believe that Obama is a Muslim compared with the $18 \%$ of the general voting age population; likewise $30 \%$ of those who disapprove of the president's job performance, believe he is a Muslim. This belief has grown since Obama took office, rising sharply from $11 \%$ of the general population in March of 2009 to the current $18 \%$. When asked how they learned of Obama's religion, $60 \%$ of respondent cite the "media" and $11 \%$ say they have "learned this through Obama's own word and behaviors." [31] It is in this claim that the consequences of such a discursive conflation become increasingly apparent and perhaps dangerous. We see a collapse of the distinction between opponent and enemy here, as Obama's political opponents see him as a political enemy.

\section{Guns Don't Kill People: (Non)Political Violence in the U.S.}

Not only "terrorists" are "wanted dead or alive" in the U.S.; the political adversaries of the Tea Party movement and other conservatives were "targeted", as are other "enemies" of the American way of life. In the run-up to 2010 mid-term Congressional elections Republican senatorial candidate Sharon Angle of Nevada told a conservative radio talk show host Lars Larson "if Congress keeps going the way that it is, people are looking toward Second Amendment remedies."'[32] Asked later about the meaning of the comment, Larson said that "if [Congress] continues to do the things it's doing, she left open the possibility of armed insurrection.'[33] Robert Spitzer, author of The Politics of Gun Control said Angle's intention was clear. Speaking on the radio show Fresh Air, Spritzer said of Angle's comments: "Its meaning is clear; 'if I do not get my way in the electoral process, I reserve for myself the right to pick up a gun and to see that I get my way in the political realm.' Her comment is the intersection of politics and armed violence.'[34]

The U.S. politician Sarah Palin identified twenty key congressional seats as essential to roll back the policies of the Obama administration. Each of these twenty seats was indicated with a gun sight over the district on a map published on Palin's web site in March of 2010. Following the publication of the map, three campaign headquarters of democratic candidates in these districts were attacked and vandalized. One of those targeted, Congresswoman Gabrielle Giffords, told MSNBC's Chuck Todd "Palin put crosshairs of a gun sight over our district; when people do that, they've got to realize there's consequences."[35] Todd responded, "campaign rhetoric and war rhetoric have always been interchangeable", not noticing the very example of calling the period approaching an election a "campaign" is a military metaphor. But Giffords held fast, 


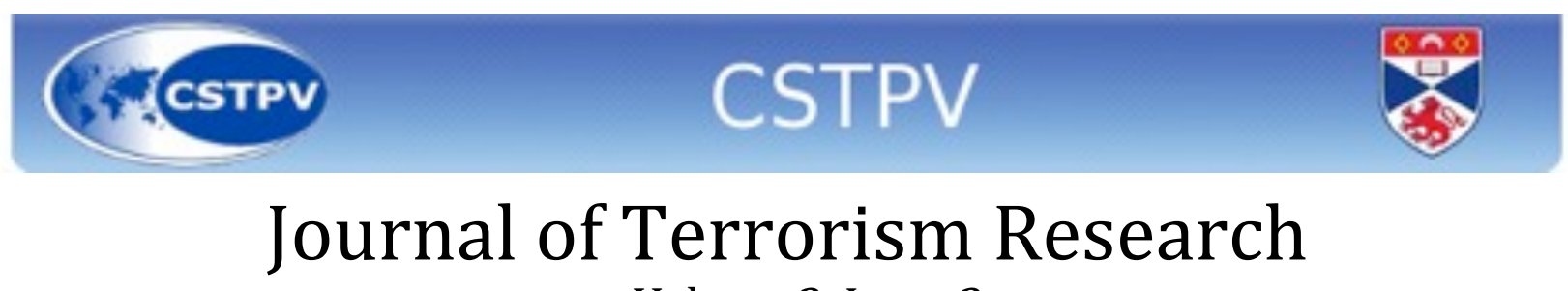

Volume 2, Issue 2

suggesting something was notably aggressive about the then recent rhetoric She said that colleagues from the House of Representatives with tenures of " 20,30 years" have said they have never seen vitriol like this.[36] It appeared that opponents were no longer part of the group self. As these opponents are seen as members of the other, and not merely part of a loyal opposition (never mind that these elements actually were the government and often are a numerical majority or at least plurality in opinion polling), it is permissible to target them with threats of violence, if not actual violence.

Giffords was threatened again at an August 2010 Tucson campaign rally; an attendee conspicuously "dropped” a handgun while Giffords defended Obama's policies. Tucson Tea Party co-founder Trent Humphries told the Arizona Daily Star that Giffords misread the dropped gun, saying "no one is targeting Gabi."[37] How wrong he was. On 7 January 2011, Giffords was shot point-blank in the head along with 19 other people, six of whom died, including nine-year old, Christina Green, and U.S. Federal judge John Roll. Investigators found that the shooter Jared L. Loughner, had engaged in methodical and meticulous planning, including hand written notes detailing his intensions that included the heading "I planned ahead."[38]

These were not the only attacks in response to Obama's policies On 18 July 2010 Byron Williams was involved in a shootout with two California Highway Patrol officers. His mother told the San Francisco Chronicle that he was "upset by the way Congress was railroading through all of these left-wing agenda items."[39] He was on his way to "begin a revolution" by attacking a California NGO, Tides, which had "become something of a whipping boy of [the U.S. conservative television personality Glenn] Beck.”[40] Beck stated frequently on his programme that the founder of the organization, Van Jones, was a "communist" responsible for "shaping the views of the President of the United States." However, following the shooting Bryon Williams was simply described as "disturbed", as was the "distraught" man who, in an eerie echo of 9/11, flew his private plane into the Austin, Texas offices of the Internal Revenue Service, killing himself, an IRS manager, and injuring 13 others in February 2010.[41] In April 2009 white supremacist Richard Poplawski went on a shooting spree killing three Pittsburgh police officers, and wounding a fourth; press reports described him as "nothing but trouble,"[42] just as Jared Loughner was repeatedly described as "distraught and disturbed." The connection between the acts of violence themselves and a permissive environment of public officials appearing to condone violence, is undermined by the parallel claims that the perpetrators of violence were disturbed, mentally unbalanced individuals, acting alone. 


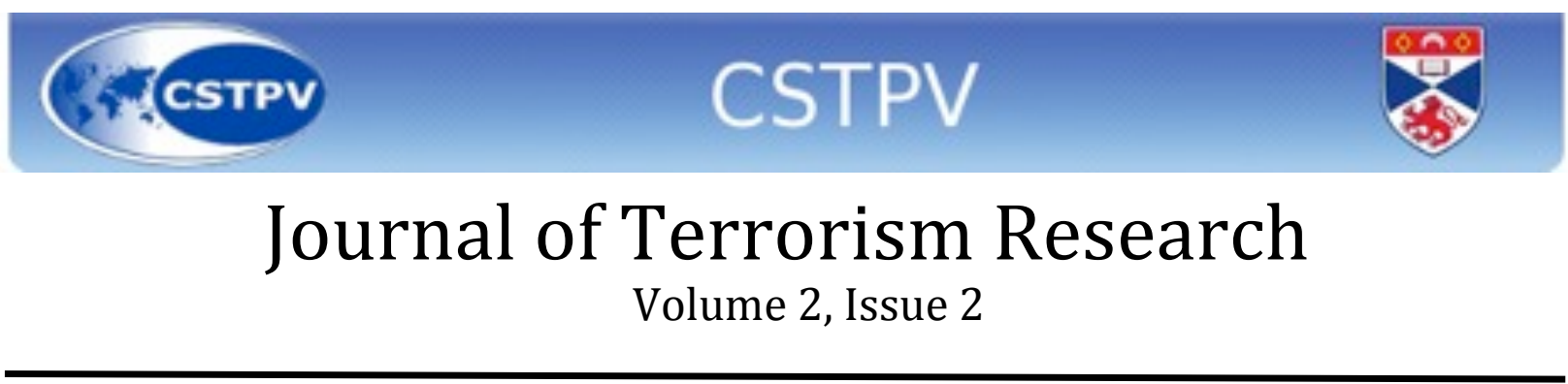

\section{Autochthones and Allochthones: A Conclusion}

These political and social reactions to distinguish between a wholly known and familiar "us" and a threatening and alien "them" is associated with what Appadurai described as the complex response to intolerable levels of uncertainty about group identities.[43] Appadurai describes how the contemporary exercises of "counting" and "naming" populations for the purposes of determining access to resources, privileges of voting and citizenship, as well as mobility and accumulation, creates a situation whereby "large numbers of people [turn] immoderately suspicious about the "real" identities of their neighbors." [44] Those suspicious of the other then work to identify further "insurgents" who wear "false masks" and who "pretend" to support the majority but in truth work against it.

This is linked to the concept of "autochthony" where claims to citizenship, rights, even the idea of personhood, are tied to one's ability to demonstrate that they come from a particular place, as opposed to migrants or foreigners. Baukje Prins and Sawitri Saharso describe how in the Netherlands, there is a growing "gap between 'autochthones and 'allochthones', between those who are already a (integrated) part of the social body, and those who are constituted as its 'outside."'[45] In places of melding cultures, labour migration, asylum seeking, and great human flows, this is a very disturbing idea. Extreme violence emerges when social trust erodes and the very existence of the other is seen as a threat Markers of everyday distinction such as speaking a different first language, or having an unfamiliar name, or eating unfamiliar foods, or practicing a different faith, quickly becomes indexes of different worldviews, and perhaps having different social values and mores. This shift entails an assertion of the ubiquity of certain cultural practices and normative positions, whereby difference becomes equated with foreignness. But such assertions ignore that there may have been differences all along, subtle and quiet differences that existed peacefully and easily with an assumption of homogeneity, even when it never existed. Difference becomes pertinent when it is accentuated and foregrounded.

These shifts come not only from propaganda and the rants of television and radio broadcasts and large-scale politics, but also from the very near, the very local, or from what Appadurai calls "the wounds of everyday life."[46] Encounters and scuffles bring misunderstandings and minor grudges, which grow with the powerful social fertilizer of rumor. Larger narratives of social distrust, providing the "proof" and the "truth" of the alien and threatening qualities of the other, validate these little doubts and suspicions, these misgivings and perceptions of betrayal. It is a powerful and destructive cycle whereby all parties know the "truth" about the other, and each encounter creates a new gaffe or misstep that increases the breadth and depth of the cleavages between groups. 


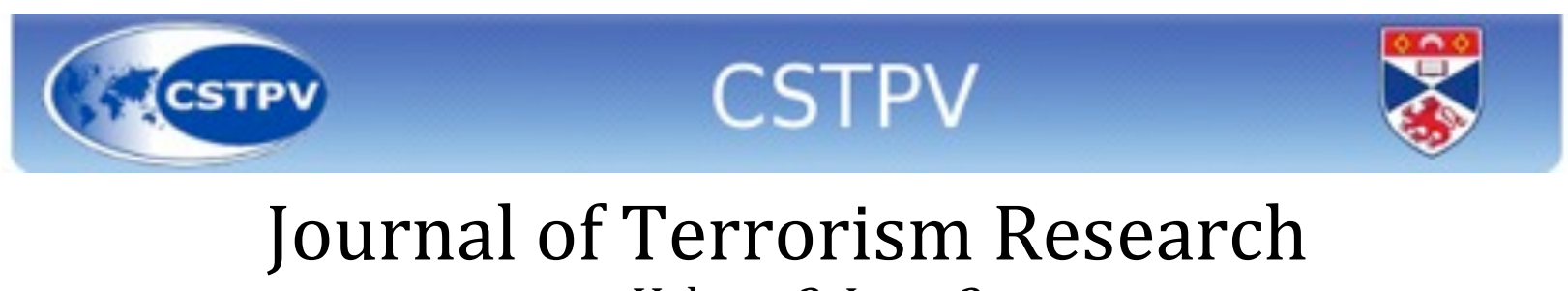

Volume 2, Issue 2

For Will Kymlicka the most dangerous situation arises when the state tries to manage the social and political rifts within the polity through securitization. In such circumstances those deemed to be a threat become the objects of suspicion, surveillance, and interdiction in the name of protecting others not deemed to pose a threat. In such cases relations between minority groups and the majority population are not a matter of normal debate, negotiation and discursive encounter, mediating demands for resource allocations or access to social spaces and position. Rather the relationship between the minority and the rest of the population is a matter of security services minimizing threat potential. In such circumstances the state will "limit the democratic process to protect itself," [47] possibly resulting in the prohibition of political or social mobilisation, or the denial of avenues of redress or grievance articulation. Kymlicka asserts that the logic of securitization itself "erodes both the democratic space to voice minority demands and the likelihood that those demands would be accepted."'[48] Here appears the danger from the far-right; demands for cultural and political homogeneity denies the expression of dissent in its many forms. Hungarians who work to protect Roma come to be seen as not "true Hungarians"; Anders Breivik attacked the Labour party's summer camp because he believed that institution was responsible for increased immigration, about which there could be no further discussion. When ideas are seen as threats to security, when there can be no more discussion, then politics have become poisonous. Kymlicka concludes that social group relations have to be "taken out of the 'security' box and placed back into the 'democratic politics' box.[49] Until that happens perhaps the people of Malmö still have reason to be afraid.

\section{Author:}

Dr. Jeffrey Stevenson Murer is the Lecturer on Collective Violence and a Research Fellow to the Centre for the Study of Terrorism and Political Violence at the University of St. Andrews. Recently he was the Principal Investigator of the British Council funded European Study of Youth Mobilisation (ESYM), which examined the motivations of young people involved in radical political and social movements and their thoughts and opinions on political violence. For ESYM, more than 800 hundred young people were interviewed in five Central European cities: Bratislava, Brno, Budapest, Krakow and Warsaw; and more that 200 academics and practitioners participated in expert panel workshops in the Nordic cities of Copenhagen, Helsinki and Stockholm. Dr. Murer is also a Scottish Institute for Policing Research Lecturer, and collaborates with colleagues from the Dutch National Police Academy and the University College Ghent on facilitating better community relations and social understanding in complex, multi-ethnic, and multi-lingual neighbourhoods. 


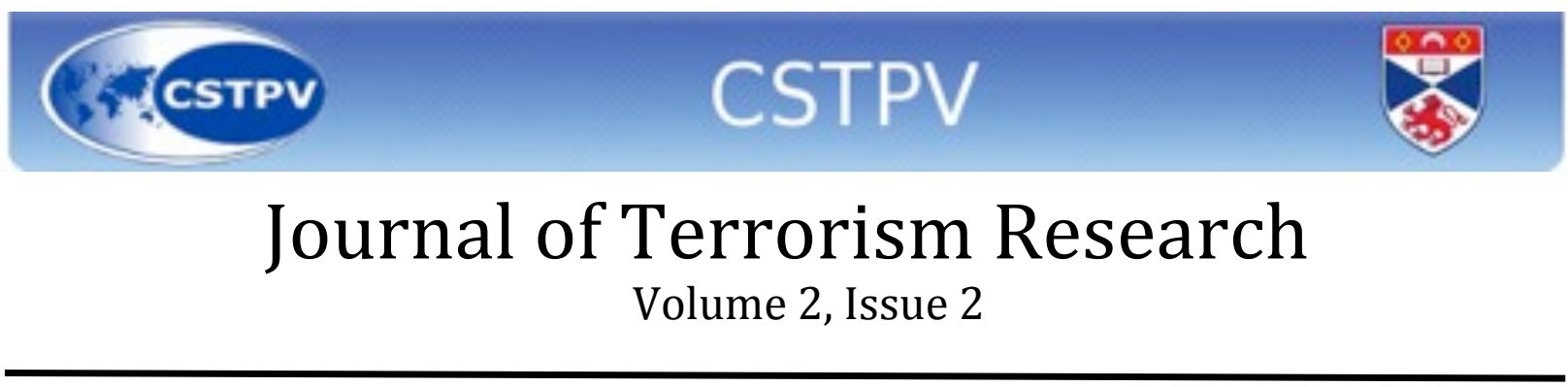

\section{Notes}

[1] Eriksen, Thomas Hylland (2011) "Den blonde terrorist dræbte 77 og forandrede Norge" Politiken PS, 31 July, p3.

[2] "Right-Wing Militants on Patrol: A New Wave of Anti-Roma Violence in Hungary”, Der Spiegel On-Line, 27 April 2011, http:// www.spiegel.de/international/europe/0,1518,759349,00.html.

[3] Waterfield, Bruno and Matthew Day (2010) "Sweden elections end in hung parliament, rise of far-right" in The Telegraph, 19 September 2010, accessed 29 October 2010, http://www.telegraph.co.uk/news/worldnews/europe/sweden/8012411/Sweden-elections-end-in-hungparliament-rise-of-far-Right.html.

[4] Larsson, Nina (2010) "Malmö still in fear as gunman remains at large" in The Local: Sweden's News in English, 29 October 2010 , accessed 29 October 2010, http://www.thelocal.se/29896/20101029/

[5] BBC Radio 4 +4:00 GMT 29 October 2010.

[6] “Sweden ‘Race Gunman’ face court in Malmö” BBC, 9 November 2010, accessed January 27, 2011 http://www.bbc.co.uk/news/worldeurope-11720008;

[7] "Malmö Shootings: Swedish Man Charged" in The Telegraph, 27 January 2011, http://www.telegraph.co.uk/news/worldnews/europe/sweden/ 8120597/Malmo-shootings-Swedish-man-charged.html

[8] Gatopoulos, Derek (2011), "Fears of Far-Right rise in crisis-hit Greece, Associated Press, 1 August.

[9] Ibid.

[10] Ibid.

[11] BBC Radio 4 +4:00 GMT 29 October 2010.

[12] Simpson, Peter Vinthagen (2010) “Two More Immigrant Shootings in Malmö” in The Local: Swedens News in English 22 October 2010, accessed 30 October http://www.thelocal.se/29758/20101022/.

[13] Ibid.

[14] Oates, Sarah (2006) "Comparing The Politics of Fear: The Role of Terrorism in Election Campaigns in Russia, the United States and Britain" in International Relations Vol. 20(4), p426. See also Philo, Greg and Mike Berry (2005) Bad News from Israel (London, Pluto Press).

[15] Aly Anne and Leia Green (2010) "Fear, Anxiety and the State of Terror" in Studies in Conflict and Terrorism Vol. (33)3, p. 272.

[16] The Times, London, 4 January 1978, in Richard Gillespie (1995), "Political Violence in Argentina: Guerrillas, Terrorists, and Carapintadas" in Terrorism in Context, Crenshaw, Martha (ed.), (University Park, PA: The Pennsylvania State University Press), p.243.

[17] Appadurai, Arjun (2005) Fear of Small Numbers: An Essay on the Geography of Angry (London, Duke University Press), p. 117.

[18] Appadurai, op cit, p. 83

[19] See Gest, Justin (2010) Apart: Alienated and Engaged Muslims in the West (London: Hurst \& Company).

[20] "Hungary One Party Rule" The Guardian 5 January 2011, http://www.guardian.co.uk/commentisfree/2011/jan/05/hungary-one-party-rule? INTCMP=SRCH, accessed 29 January 2011.

[21] "Far Right Demands Budaházy’s Release" Budapest Times 21 September 2010, accessed 30 October 2010 http://www.budapesttimes.hu/ index.php?option=com_content\&task=view\&id=15327\&Itemid=159

[22] Ibid.

[23] "Neo-Nazis Terrorize Roma in Hungarian Village" Hungarian Watch, 18 March 2011, http://hungarianwatch.wordpress.com/2011/03/18/ neo-nazis-terrorize-roma-in-hungarian-village/

[24] "Right-Wing Militants on Patrol: A New Wave of Anti-Roma Violence in Hungary", Der Spiegel On-Line, 27 April 2011, http:// www.spiegel.de/international/europe/0,1518,759349,00.html

[25] Ibid.

[26] Ibid.

[27] BBC 4 October 2010, accessed 30 October 2010, http://www.bbc.co.uk/news/world-europe-11464025

[28] Ibid.

[29] Mackey, Robert (2010) "Fire at Mosque Spreads Fear" in New York Times, 30 August 2010, accessed 30 October 2010 http:// thelede.blogs.nytimes.com $/ 2010 / 08 / 30 /$ fear-spreads-after-fire-at-tennessee-mosque-site/. 


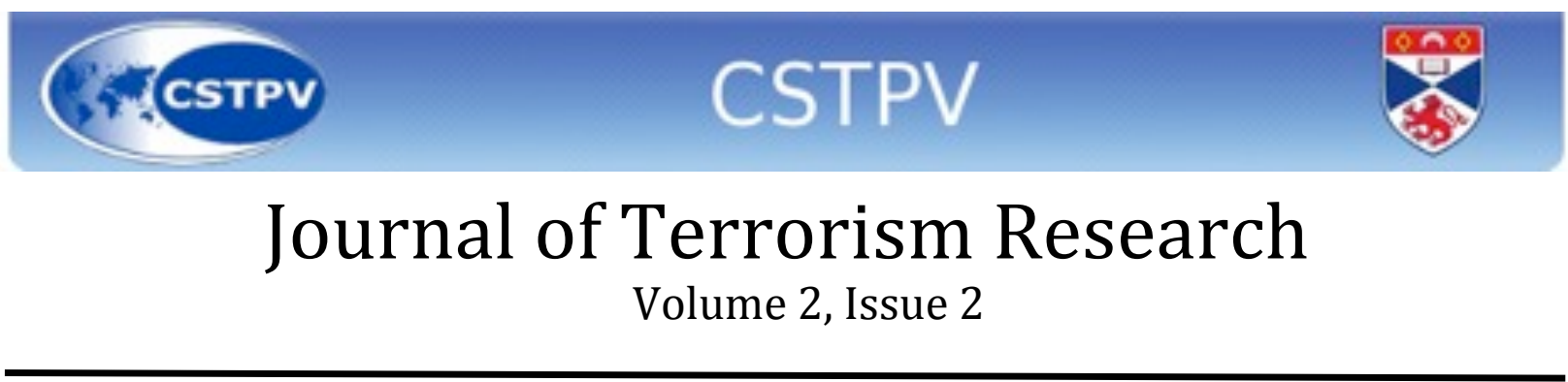

[30] Goodstein Laura (2010) “Battles Around Nation over Proposed Mosques” in New York Times 7 August 2010, accessed 30 October 2010, http://www.nytimes.com/2010/08/08/us/08mosque.html.

[31] "Growing Number of Americans Say Obama is a Muslim" in Pew Research Center Publications 19 August 2010, accessed 30 October 2010 http://pewresearch.org/pubs/1701/poll-obama-muslim-christian-church-out-of-politics-political-leaders-religious

[32] Sargent, Greg, 2010 "Sharon Angle Floats the Possibility of Armed Insurrection" in The Washington Post, 15 June 2010, http:// voices.washingtonpost.com/plum-line/2010/06/sharron_angle floated_possibil.html, accessed 28 January 2011.

[33] Ibid.

[34] “After the Tucson Shootings, the NRA shows it Strength" on Fresh Air, NPR, 27 January 2011, http://www.npr.org/2011/01/27/133247508/ the-history-and-growing-influence-of-the-nra, accessed 29 January 2011.

[35] Rich, Frank (2011) "No one listened to Gabrielle Giffords" in The New York Times, 15 January 2011 http://www.nytimes.com/2011/01/16/ opinion/16rich.html?partner=rssnyt\&emc=rss.

[36] Ibid.

[37] Ibid.

[38] Lacey, Marc (2011) “Evidence Points to Meticulous Planning” in The New York Times, 9 January 2011 http://www.nytimes.com/2011/01/10/ us/10giffords.html, accessed 27 January 2011.

[39] "I-580 Shootout Suspect Angry at Left-Wing Politics" in The San Francisco Chronicle, 18 July 2010,

http://www.sfgate.com/cgi-bin/article.cgi?f=/c/a/2010/07/18/BAG71EG92P.DTL, access 27 January 2011.

[40] Rayfield, Jillian (2010) “Organization Targeted by Anti-Gov CA Shooting Suspect was Frequent Topic on Glenn Beck's Show” in TPMMuckraker, 21 July 2010, http://tpmmuckraker.talkingpointsmemo.com/2010/07/organization targeted_by_anti-

govt ca_shooting_suspect_was frequent topic_on_glenn_becks_show_video.php, accessed 27 July 2011. [4]1] "Man Crashes plane into Texas IRS Office" in The New York Times, 19 February 2010 http://www.nytimes.com/2010/02/19/us/19crash.html, access 27 January 2011.

[42] "Carnage in Pittsburgh" in Hatewatch from the Southern Poverty Law Centre, April 6 2009, http://www.splcenter.org/blog/2009/04/06/ carnage-in-pittsburgh-deadliest-extremist-attack-on-law-enforcement-officers-since-oklahoma-city/, accessed 27 January 2011, and "Who is Richard Poplawski?' WTAE News 6 April 2009, http://www.wtae.com/news/19096134/detail.html, accessed 28 January 2011.

[43] Appadurai, op cit, p.88 and Appadurai, Arjun (1998), "Dead Certainty: Ethnic Violence in the Era of Globalization" Public Culture 10(2), pp. 225-47.

[44] Ibid. p. 88.

[45] Prins, Baukje and Sawitri Saharso (2010) "From Toleration to Repression: the Dutch Backlash Against Multiculturism" in The Multiculturism Backlash: European Discourses, Policies and Practices, Vertovec, Steven and Susanne Wessendorf (eds.), London: Routledge, 2010, pp. 86-87.

[46] Ibid. p. 91.

[47] Kymlicka, Will (2010) "The Rise and Fall of Multiculturalism? New Debates on Inclusion and Accommodation in Diverse Societies" in The Multiculturism Backlash: European Discourses, Policies and Practices, Vertovec, Steven and Susanne Wessendorf (eds.), London: Routledge, 2010, pp. 44-45.

[48] Ibid. p. 44.

[49] Ibid. p. 44. 